\title{
The Assessment of Periodontal Health in Children Age 12 to 15
}

\author{
Bojana Davidović', Mirjana Ivanović2 ${ }^{2}$ Svjetlana Janković', Jelena Lečić ${ }^{3}$ \\ 1Department of Preventive Dentistry and Pedodontics, Faculty of Medicine, University of East Sarajevo, Foča, \\ Bosnia and Herzegovina; \\ 2Department of Preventive Dentistry and Pedodontics, Faculty of Dental Medicine, University of Belgrade, Belgrade, \\ Serbia; \\ 3Department of Periodontology and Oral Medicine, School of Medicine, University of East Sarajevo, Foča, \\ Bosnia and Herzegovina
}

\begin{abstract}
SUMMARY
Introduction Periodontal diseases and primarily gingivitis occur relatively early in the childhood. It was found that $8.8 \%$ of children 3-6 years old had gingivitis and that number increased with age. Gingivitis is especially common during puberty and mixed dentition. The aim was to determine the prevalence and characteristics of gingival and periodontal diseases in children age twelve and fifteen in Republika Srpska.

Material and Methods The study included 506 students of both genders from six schools on the territory of the municipalities Foca, Cajnice and Kalinovik. For the evaluation of oral hygiene and periodontal status, indices suitable for research in pediatric population were used: Greene-Vermillion Debris Index (DI), Greene's Calculus Index (CI), Oral Hygiene Index (OHI) and Community Periodontal Index of Treatment Needs (CPITN). The evaluation was carried out in accordance with the criteria for the diagnosis and non- communicable diseases, established in 1997 in Geneva. Results The average DI value for all children was 0.86 , the average $\mathrm{Cl} 0.13$, and $\mathrm{OHI}$ was 0.99 . Healthy periodontium had $14.6 \%$ of respondents, while deep periodontal pockets of $4-5 \mathrm{~mm}$ were found in $8.7 \%$ of fifteen-year-old children. Conclusion A significant prevalence of gingivitis was found among examined children. It is necessary to highlight the importance of primary prevention measures, health education, proper training and regular oral hygiene, as well as regular check-ups in order to achieve better periodontal health in children.
\end{abstract}

Keywords: gingivitis; periodontal disease; epidemiology; health; children

\section{INTRODUCTION}

Gingiva, periodontal tissue, cement and alveolar bone are surrounding structures that provide tooth support; however, they are developmentally, topographically and functionally closely related. Pathological processes that affect all parts of periodontium are referred as periodontitis. These destructive changes lead to gradual periodontal anatomical and functional disintegration, teeth loosening and eventually teeth loss [1].

For a long time it has been considered that gingivitis and periodontal diseases occur as a result of periodontal tissue aging leading to inflammation and gingival recession. Unfortunately, numerous studies have indicated that it is not just adult disease, periodontal diseases and especially gingivitis occurs relatively early, even in children. It has been found that $8.8 \%$ of preschool children age 3-6 years had some initial forms of periodontal disease, and with age this percentage was increasing $[2,3]$. Gingivitis is common during puberty and mixed dentition $[2,4]$. There is a slight declining in the prevalence of periodontal diseases in adolescence, increasing again with age. It is believed that hormonal changes cause rapid increase of gingivitis prevalence in puberty, while declining in adolescence is the result of better understanding of oral health importance and better oral hygiene. Onset of puberty and increase in levels of sex hormones are some explanations for the increased prevalence of gingivitis in eleven-year-old children. Estrogen increases the celularity while progesterone increases permeability of blood vessels in gingiva. Estradiol also provides favorable conditions for black pigmented microorganisms growth associated with gingivitis [5].

It is known today that periodontal diseases are caused by bacteria found in dental plaque, or biofilm, and the severity of periodontal disease is related to the level of oral hygiene $[1,6]$. A number of other factors, directly or indirectly associated with dental plaque influence the beginning, the course and the progression of periodontal diseases. These factors enable rapid creation, accumulation and retention of dental plaque, facilitating the negative effect of harmful metabolic products of microorganisms on periodontium. This includes supragingival and subgingival calculus, anatomical anomalies of 
the teeth and periodontium, food impaction, iatrogenic causes, bad habits, dental caries, gingival lesions, traumatic occlusion, as well as general factors (gender, race, age, stress) and systemic disease [7, 8].

Gingivitis does not necessarily progress to periodontal disease. It has been found that gingivitis preceded periodontitis, although its presence was no longer necessary for the progression of lesions [9]. This can be argued on the basis that large number of people can have prolonged presence of gingivitis, with no pocket development or alveolar bone loss [10].

The aim of this study was to determine the prevalence and characteristics of gingival and periodontal diseases in twelve and fifteen year old children in the selected areas of Republika Srpska.

\section{MATERIAL AND METHODS}

Estimated epidemiological study comprised two age groups of children, twelve and fifteen years old living on the territory of the municipalities Foca, Cajnice, Kalinovik, 506 in total. Participating children were from six elementary schools, four from Foca and two from other two towns. After obtaining approval from the Ethical Committee of the Medical Faculty in Foca, and consent from school principals as well as the informed consent signed by parents/guardians, the study was conducted in 2007 by pre-arranged protocol. The assessment was performed using a periodontal probe and a mirror under natural light.

Out of many indices for gingival and periodontal health assessment, those suitable for use in children were selected. The evaluation was carried out in accordance with the criteria for the diagnosis and non-communicable diseases, established in 1997 in Geneva [11, 12].

The amount of soft debris on teeth (dental plaque, materia alba, food remnants) was determined by GreeneVermillion index of soft deposits or "debris index" (DI) [11]. Surfaces of six representative teeth for the whole dentition were used to determine this index. Gingival probing was performed only on fully erupted teeth. The average index was obtained by summing the index values for each tooth and dividing this sum with the number of observed teeth. If a tooth was missing, a neighboring tooth could not replace it. Greene's hard debris index or "calculus index" (CI) was determined on the same teeth as for the debris index. After determining the presence of hard deposits on representative teeth, the average index was obtained by summing the obtained values and dividing it with the number of examined teeth. Both indices together gave oral hygiene index (OHI), which is frequently used in epidemiological studies [11].

Community Periodontal Index of Treatment Needs was used for periodontal status assessment (CPITN) [12], often in the literature referred as CPI (index for community and treatment needs). A special periodontal probe with $0.5 \mathrm{~mm}$ diameter bead on the tip to facilitate subgingival calculus detection was used. Since it was approved by the World Health Organization, it is often named the
WHO probe. Periodontal health evaluation in children and adolescents, 7-19 years of age using this index was modified according to the WHO recommendations. Only six permanent teeth were examined: 16, 11, 26, 36, 31 and 46 . When assessing periodontal status in children age 7-11 years, it was not recommended to measure the depth of gingival sulcus or pocket. In twelve-years-olds periodontal status was determined based on the clinical condition of gingiva and hard deposits, if present, while in fifteen-year-olds periodontal pockets depth was measured using periodontal probe. The worst periodontal status was recorded for each sextant. Individual CPITN score represented the most progressive finding in the examined sextants. A risk for periodontal disease was assessed based on final score. For example, the children with value 1 would have a potential risk for developing gingivitis.

\section{RESULTS}

The average debris index value for all children was 0.86 . Although variations in results between schools were observed, the maximum value was found in children attending elementary school Veselin Masleša from Foca, intergroup analysis did not reveal statistical significance. Boys in all schools, regardless of age, had higher average value for DI as compared to girls (1.01 vs. 0.68 ). Student's t-test showed highly statistically significant difference between genders $(t=6.333 ; \mathrm{p}<0.01)$. The group of older children (fifteen-year-olds) had higher average DI value (0.92) as compared to the younger (twelve-yearolds) group (0.82). The difference was statistically significant $(\mathrm{t}=1.967 ; \mathrm{p}<0.05)$.

The highest value of calculus index was recorded in children from elementary school Sveti Sava in Miljevina, while the lowest value was recorded in elementary school Ljutica Bogdan from Kalinovik. The difference was not significant. The average value of $\mathrm{CI}$ for all children was 0.13 . Boys had higher value of $\mathrm{CI}$ as compared to girls, but the difference was not statistically significant. Twelveyear-olds had higher average CI value as compared to fifteen-year-olds (0.17 vs. 0.09) and the difference was statistically significant as shown by the value of Student's $\mathrm{t}$-test $(\mathrm{t}=3.201 ; \mathrm{p}<0.01)$.

The average $\mathrm{OHI}$ value for all children was 0.99 . The average $\mathrm{OHI}$ value in boys (1.16) and fifteen-year-olds (1.11) was greater than in girls (0.78) and twelve-yearolds (0.91), respectively. Differences between observed characteristics were statistically significant between genders $(t=5.589 ; \mathrm{p}<0.01)$ and age groups $(t=2.705 ; \mathrm{p}<0.01)$.

Prevalence and incidence of periodontal diseases was assessed using CPITN index (Table 1). The highest values were recorded for the elementary school Veselin Maslesa in Foca, and the lowest value for Ljutica Bogdan in Kalinovik. ANOVA showed highly statistically significant difference between $\mathrm{OHI}$ value for the children from Veselin Maslesa in Foca and children from other schools $(\mathrm{F}=3.933 ; \mathrm{p}<0.01)$. Multiple comparisons between other schools did not show statistically significant difference. The average value of $\mathrm{OHI}$ for all children was 1.29. 
Table 1. Distribution of CPITN mean values in relation to the school Tabela 1. Raspodela srednje vrednosti CPITN u odnosu na školu

\begin{tabular}{|c|c|}
\hline $\begin{array}{c}\text { School } \\
\text { Škola }\end{array}$ & CPITN \\
\hline VMF & 1.54 \\
\hline VMB & 1.2 \\
\hline SSF & 1.23 \\
\hline SSM & 1.14 \\
\hline LJBK & 1.02 \\
\hline JDČ & 1.24 \\
\hline Total \\
Ukupno & 1.29 \\
\hline
\end{tabular}

VMF - Veselin Masleša, Foča (city school); VMB - Veselin Masleša, Brod (suburban school); SSF - Sveti Sava, Foča (city school); SSM - Sveti Sava, Miljevina (suburban school); LJBK - Ljutica Bogdan, Kalinovik (city school); JDČ - Jovan Dučić, Čajniče (city school)

VMF - Veselin Masleša, Foča (gradska škola); VMB - Veselin Masleša, Brod (vangradska škola); SSF - Sveti Sava, Foča (gradska škola); SSM - Sveti Sava, Miljevina (vangradska škola); LJBK -Ljutica Bogdan, Kalinovik (gradska škola); JDČ - Jovan Dučić, Čajniče (gradska škola)

Table 2. Periodontal condition of the examined children according to the highest CPITN scores per person

Tabela 2. Stanje periodoncijuma kod ispitivane dece prema najvišim CPITN bodovima po osobi

\begin{tabular}{|l|c|}
\hline $\begin{array}{l}\text { Periodontal condition } \\
\text { Stanje periodoncijuma }\end{array}$ & CPITN \\
\hline $\begin{array}{l}\text { Healthy } \\
\text { Zdrav }\end{array}$ & $14.6 \%$ \\
\hline $\begin{array}{l}\text { Bleeding } \\
\text { Krvari }\end{array}$ & $50.8 \%$ \\
\hline $\begin{array}{l}\text { Calculus } \\
\text { Konkrementi }\end{array}$ & $25.9 \%$ \\
\hline $\begin{array}{l}\text { Shallow pockets }(4-5 \mathrm{~mm}) \\
\text { Plitki džepovi }(4-5 \mathrm{~mm})\end{array}$ & $8.7 \%$ \\
\hline
\end{tabular}

Differences in periodontium were found between different genders and age groups. Boys (1.39) had higher average values of CPITN index than girls (1.17) and statistically significant difference was found $(t=2.944$; $\mathrm{p}<0.01)$. Statistically significant difference $(t=2.022$; $\mathrm{p}<0.05$ ) was also found for the values of index in relation to the age of children (twelve-year-olds - 1.23; fifteenyear-olds - 1.38).

Healthy periodontium was present in $14.6 \%$ of respondents, while $8.7 \%$ of fifteen-year-olds had periodontal pockets. The most common value of CPITN index value was 1 and it was found in $50.8 \%$ of respondents (27.9\% boys and $22.9 \%$ girls or $35.4 \%$ twelve-year-old and $15.4 \%$ fifteen-year-old children; Table 2). Observed difference was highly statistically significant between different gender $\left(\chi^{2}=15.824 ; \mathrm{p}<0.01\right)$ and age of subjects $\left(\chi^{2}=19.423 ; \mathrm{p}<0.01\right)$. Boys and twelve-year-olds had higher values of CPITN index.

\section{DISCUSSION}

Epidemiological studies are important for research about periodontal diseases, their occurrence and prevalence. Results obtained by epidemiological studies would help in finding the appropriate measures for prevention and therapy of periodontal disease, planning of material resources, staff and other measures for prevention and control. Data about the prevalence of gingivitis and periodontal disease is quite different in the literature due to the different methodologies used. Based on different studies it can be concluded that the prevalence of gingivitis and periodontal disease is high, but severity and progression are declining. Due to the inevitable subjectivity in assessing the severity of gingivitis and inability to objectively determine bone destruction without radiographic images, obtained results are variable.

A recent study conducted in Bosnia and Herzegovina showed that $43 \%$ of twelve-year-olds had healthy periodontal tissue, although the same number of respondents had bleeding on probing [13]. Students who were involved in the preventive program showed significantly better oral hygiene status (OHI 0.95) than children not involved in the program [14]. The study conducted in twelve-year-olds in Montenegro reported the average value of DI 1.086. Boys from rural parts of Montenegro had significantly more soft debris. The average value of CI for the same subjects was 0.65 . Also, $64 \%$ of twelveyear-olds had healthy periodontal tissue while $31.89 \%$ showed bleeding on probing [15]. Lower values for soft and hard deposits in twelve and fifteen year olds from Kosovo and Metohija were found in the rural area as compared to urban. Healthy periodontium was found in $14.6 \%$ of respondents while larger number of respondents (40.8\%) had supra and subgingival calculus as well as fillings overhangs [16]. These results are in compliance with our results. The latest data obtained from the survey conducted in 2009 by the Department of Pediatric and Preventive Dentistry, University of Belgrade, for the purpose of designing the preventive program in the Republic of Serbia, reported average gingival index of 0.5 in examined twelve-year-old children. Healthy periodontium in at least three sextants had $46 \%$ fifteen-year-olds. The best results were found in Zaječar district (96\%) and North Banat district (76\%), while localities with the worst results were Nis (16\%) and Zlatibor district (16\%) [17]. Bleeding on probing and dental calculus were found in $82 \%$ of the youngest respondents (15-19 years) in the study conducted in Zagreb [18].

Petersen and Ogawa [8] compared the values of the CPITN index in the world among different age groups in order to improve the prevention of periodontal disease. About 20\% of European youth population (15-19 years) had healthy periodontium, while more than 55\% had calculus and bleeding on probing. A study conducted in the southern Italy indicated that for most respondents the tooth 11 was less commonly affected by calculus or bleeding on probing, while at the same time the most frequently affected tooth was 46 [19]. The value 1 of CPITN index was recorded in $39.7 \%$ of the examined Hungarian twelve-year-olds, while $28 \%$ had healthy periodontium [20]. Gingival bleeding and presence of calculus were determined by periodontal index in $90 \%$ of twelveyear-olds in Portugal, while $74.5 \%$ had satisfactory oral hygiene $(\mathrm{OHI}=0.7-1.8)$ [21]. Children of the same age from the private schools in Abu Dhabi had the highest percentage of satisfactory oral hygiene $60.33 \%$ and poor oral hygiene was found in $3.30 \%$ only [22]. Evaluated by 
periodontal index 57\% of twelve-year-olds from West Africa had gingivitis or calculus, and only $22 \%$ had healthy periodontium [23]. Six-year study in Hong Kong followed the periodontal health of children from childhood (12 years), during adolescence ( 15 years) to early adulthood (18 years). They found that the percentage of children with healthy periodontium decreased with age, but the percentage of children with calculus increased (from $57.9 \%$ in twelve to $95.5 \%$ in eighteen years old children) [24]. Bleeding on brushing occurred in $15.9 \%$ of twelve-year-olds in Rio de Janeiro [25].

\section{CONCLUSION}

Gingival and periodontal health of examined children was not satisfactory. According to the obtained results it can be concluded that only $15 \%$ of examined children had healthy periodontium. Of a special concern is the fact that $8 \%$ of adolescents had signs of periodontal disease or presence of $4-5 \mathrm{~mm}$ deep periodontal pockets. It is necessary to organize better preventive service and encourage oral health promotion and popularization.

\section{REFERENCES}

1. Djajić D, Djukanović D. Parodontologija i tzv. "fokalna infekcija". Beograd: Drasler partner; 2006.

2. Vulović MD, Beloica D, Gajić M, Stevanović R, Ivanović M.D, Carević MR, et al. Preventivna stomatologija. Beograd: Naučna knjiga; 2002.

3. Ivanović M, Vulović M, Cekić D, Lekić P. Uticaj fluorida iz pijaćih voda na pojavu karijesa i gingivitisa u dvanaestogodišnjaka. Stomatološki glasnik Srbije. 1988; 35:95-102.

4. Vojinović J, Tataić E, Anđelić P, Pintarić J. Preventivni program u stomatologiji. Beograd: Naučna knjga; 1990.

5. Heasman PA, Murray JJ. Periodontal diseases in children. In: Welbury RR, editor. Pediatric Dentistry. Oxford: Oxford University Press; 1997. p.201-221.

6. Van der Weijden F, Slot DE. Oral hygiene in the prevention of periodontal diseases: the evidence. Periodontol 2000. 2011; 55:104-23.

7. Beloica D, Vulović M, Stevanović R, Carević M, Ivanović MD, Vulićević ZR, et al. Dečija stomatologija - praktikum. Beograd: Stomatološki fakultet Univerziteta u Beogradu; 2006.

8. Petersen PE, Ogawa H. Strengthening the prevention of periodontal disease: the WHO approach. J Periodontol. 2005; 76:2187-93.
9. Greene JC. Discussion: natural history of periodontal disease in man. J Clin Periodontol. 1986; 13:441-4.

10. Listgarten MA, Schifter CC, Laster L. 3-year longitudinal study of the periodontal status of an adult population with gingivitis. J Clin Periodontol. 1985; 12:225-38.

11. Greene JC, Vermillion JR. The simplified oral hygiene index. J Amer Dent Assoc. 1964; 68:7-13.

12. World Health Organization. Oral Health Surveys: Basic Methods. 4th ed. Geneva: WHO; 1997.

13. Muratbegović A, Marković N, Kobašlija S, Zukanović A. Indeksi oralnog zdravlja i hipomineralizacija kutnjaka i sjekutića kod bosanske djece $u$ dobi od 12 godina. Acta Stomatol Croat. 2008; 42:155-63.

14. Knežević R, Skrobić I, Ćelić B, Zubović N. Primena programa prevencije za unapređenje oralnog zdravlja dece školskog uzrasta u Banjaluci. Stomatološki glasnik Srbije. 2009; 56:123-9.

15. Đuričković $M$, Ivanović M. Stanje oralnog zdravlja kod dece uzrasta od 12 godina u Crnoj Gori. Vojnosanit Pregl. 2011; 68:550-5.

16. Martinović B, Milojković Z, Cvetković A, Stojanović B. Stanje zdravlja parodoncijuma školske dece sa područja Kosova i Metohije. Praxis medica. 2009; 37:61-4.

17. Ivanović M, Carević M, Marković D. Program preventivne stomatološke zdravstvene zaštite dece i omladine. Stomatološki glasnik Srbije. Zbornik referata i radova XXVI Simpozijuma zdravstvenog vaspitanja u stomatologiji, Kragujevac; 2010. p.36-44.

18. Ivić-Kardum M. Prevalencija progresivnih parodontnih bolesti zagrebačkog stanovništva. Acta Stomatol Croat. 2000; 34:149-56.

19. Ferrazzano GF, Scaravilli MS, Ingenito A. Dental and periodontal health status in Campanian children and relation between caries experience and socio-economic behavioural factors. Eur J Paediatr Dent. 2006; 7:174-8.

20. Szöke J, Petersen PE. Evidence for dental caries decline among children in an East European country (Hungary). Community Dent Oral Epidemiol. 2000; 28:155-60.

21. De Almeida CM, Petersen PE, Jesus André S, Toscano A. Changing oral health status of 6- and 12-year-old schoolchildren in Portugal. Community Dent Health. 2003; 20:211-6.

22. ur Rehman MM, Mahmood N, ur Rehman B. The relationship of caries with oral hygiene status and extra-oral risk factors. J Ayub Med Coll Abbottabad. 2008; 20:103-8.

23. Varenne B, Petersen PE, Ouattara S. Oral health status of children and adults in urban and rural areas of Burkina Faso, Africa. Int Dent 1. 2004; 54:83-9.

24. Lu HX, Wong MCM, Lo ECM, MCGrath C. Trends in oral health from childhood to early adulthood: a life course approach. Community Dent Oral Epidemiol. 2011; 39:352-60.

25. Castro RAL, Portela MC, Leaõ AT, Vasconcellos MTL. Oral healthrelated quality of life of 11- and 12-year-old public school children in Rio de Janeiro. Community Dent Oral Epidemiol. 2011; 39:336-44.

Received: 08/02/2012 • Accepted: 30/04/2012 


\title{
Procena stanja zdravlja parodoncijuma dece uzrasta od 12 i 15 godina
}

\author{
Bojana Davidović1, Mirjana Ivanović2, Svjetlana Janković1, Jelena Lečić3 \\ ${ }^{1}$ Katedra za preventivnu i dječiju stomatologiju, Medicinski fakultet, Univerzitet u Istočnom Sarajevu, Foča, Bosna i Hercegovina; \\ ${ }^{2 K}$ Kinika za preventivnu i dečju stomatologiju, Stomatološki fakultet, Univerzitet u Beogradu, Beograd, Srbija; \\ ${ }^{3}$ Katedra za parodontologiju i oralnu medicinu, Medicinski fakultet, Univerzitet u Istočnom Sarajevu, Foča, Bosna i Hercegovina
}

\begin{abstract}
KRATAK SADRŽAJ
Uvod Oboljenja parodoncijuma, a pre svega gingivitisi, javljaju se relativno rano, već u dečjem uzrastu. Ustanovljeno je da 8,8\% dece uzrasta 3-6 godina boluje od gingivitisa i da se sa godinama ovaj procenat povećava. Pojava gingivitisa je posebno česta u periodu smene zuba i u pubertetu. Cilj rada bio je da se utvrde rasprostranjenost i odlike oboljenja gingive i parodoncijuma kod dece uzrasta od 12 i 15 godina u Republici Srpskoj.

Materijal i metode rada Ispitivanjem je obuhvaćeno 506 učenika oba pola iz šest škola koji žive na teritoriji opština Foča, Čajniče i Kalinovik. Za procenu oralne higijene i stanja zdravlja parodoncijuma korišćeni su indeksi pogodni za istraživanja kod dece: indeks mekih zubnih naslaga (IMN), indeks tvrdih zubnih naslaga (ITN), indeks oralne higijene (IOH) i tzv. indeks u zajednici i potreba lečenja (engl. community periodontal index of treatment needs - CPITN). Ocenjivanje je vršeno u skladu s kriterijumima za dijagnozu i nezarazne bolesti koji su ustanovljeni 1997. godine u Ženevi.

Rezultati Prosečna vrednost IMN bila je 0,86, ITN 0,13, a IOH 0,99. Zdrav parodoncijum je zabeležen kod $14,6 \%$ ispitanika, dok su kod $8,7 \%$ petnaestogodišnjaka utvrđeni parodontalni džepovi dubine $4-5 \mathrm{~mm}$.

Zaključak Kod ispitivane dece utvrđena je značajna rasprostranjenost gingivitisa. Neophodno je ukazati na značaj primarne prevencije i kroz mere zdravstvenog vaspitanja, obuku o pravilnoj i redovnoj oralnoj higijeni i redovne kontrolne preglede obezbediti bolje stanje zdravlja parodoncijuma kod dece.
\end{abstract}

Ključne reči: gingivitis; parodontopatije; epidemiologija; zdravlje; deca

\section{UVOD}

Tkiva kao što su gingiva, parodoncijum, cement i alveolarna kost okružuju zub i pružaju mu potporu, a razvojno, topografski i funkcionalno su u tesnoj vezi. Patološki procesi koji zahvataju sve delove parodoncijuma označavaju se kao parodontopatije. To su destruktivne promene koje vode ka postepenom obolevanju parodoncijuma, anatomskoj i funkcionalnoj dezintegraciji, rasklaćenju i gubitku jednog ili većeg broja zuba [1].

Dugo se smatralo da su gingivitis i parodontopatije bolesti koje nastaju kao posledica starenja parodontalnih tkiva, pri čemu dolazi do zapaljenja i povlačenja desni. Nažalost, mnogobrojna istraživanja pokazuju da to nisu samo oboljenja odraslih, već da se parodontopatije, a pre svega gingivitisi, javljaju relativno rano, još u dečjem uzrastu. Ustanovljeno je da $8,8 \%$ dece uzrasta 3-6 godina ima neke od početnih oblika oboljenja parodoncijuma i da se sa godinama ovaj procenat povećava [2,3]. Pojava gingivitisa je posebno česta u periodu smene zuba i u pubertetu $[2,4]$. U adolescenciji dolazi do blagog smanjenja prevalencije, koja se vremenom opet povećava. Smatra se da su hormonske promene uzrok naglog povećanja broja osoba sa gingivitisom $\mathrm{u}$ pubertetu, a da je njihovo smanjenje $\mathrm{u}$ adolescenciji rezultat shvatanja značaja oralnog zdravlja i bolje higijene usta i zuba. Početak puberteta i povećanje nivoa polnih hormona jedno je od objašnjenja za porast prevalencije gingivitisa kod jedanaestogodišnjaka. Estrogen povećava celularnost tkiva, a progesteron propustljivost krvnih sudova gingive. Estradiol takođe obezbeđuje pogodne uslove za rast mikroorganizama s crnim pigmentom, koji su u vezi sa gingivitisom [5].

Danas se zna da su oboljenja parodoncijuma izazvana bakterijama koje se nalaze u zubnom plaku, odnosno biofilmu, i da je težina parodontalnih oboljenja u vezi sa stanjem higijene usta i zuba $[1,6]$. Na sam početak, tok i brzinu nastanka parodontopa- tija utiču i drugi faktori koji su u direktnoj ili indirektnoj vezi s mikroorganizmima zubnog plaka. Dejstvo ovih faktora se ogleda u omogućavanju bržeg stvaranja, akumuliranja i zadržavanja zubnog plaka, čime se olakšava dejstvo štetnih metaboličkih produkata mikroorganizama na sam parodoncijum. Značajni faktori su: zubni kamenac, subgingivalni konkrementi, anatomske anomalije parodoncijuma i zuba, impakcija hrane, jatrogeni uzroci, loše navike, karijesni zubi, lezije gingive, traumatska okluzija, kao i opšti faktori (pol, rasa, starost, stres) i sistemska oboljenja [7, 8].

Gingivitis ne mora obavezno da progredira u parodontopatiju. Potvrđeno je da gingivitis prethodi parodontopatiji, ali da nije neophodan za dalje napredovanje lezije, kada proces zahvati lateralni parodoncijum [9]. Ova tvrdnja proizlazi iz činjenice da kod velikog broja osoba često već dugo postoji gingivitis, bez razvoja džepova ili gubitka alveolarne kosti [10].

Cilj ovog istraživanja bio je da se utvrde rasprostranjenost $\mathrm{i}$ odlike oboljenja gingive i parodoncijuma kod dece uzrasta od 12 i 15 godina u Republici Srpskoj.

\section{MATERIJAL I METODE RADA}

Istraživanjem je obuhvaćeno 506 dece uzrasta od 12 i 15 godina koja žive na teritoriji opština Foča, Čajniče i Kalinovik. Deca su bila iz šest osnovnih škola: četiri iz Foče i po jedna iz opštine Čajniče i Kalinovik. Nakon odobrenja Etičkog komiteta Medicinskog fakulteta u Foči, te dobijene saglasnosti direktora škola, pisane saglasnosti roditelja, odnosno staratelja dece, istraživanje je po unapred dogovorenom redu izvedeno tokom 2007. godine. Ispitivanje je vršeno pomoću parodontalne sonde i ogledalceta pri prirodnom osvetljenju.

Od brojnih indeksa za procenu stanja zdravlja gingive i parodoncijuma, odabrani su oni koji su pogodni za korišćenje $u$ 
dečjoj stomatologiji. Ocenjivanje je vršeno u skladu s kriterijumima za dijagnozu i nezarazne bolesti, koji su ustanovljeni 1997. godine u Ženevi [11, 12].

Količina svih mekih naslaga na zubima (zubnog plaka, bele materije, ostataka hrane) određivan je prema indeksu mekih naslaga (IMN) Grin-Vermiliona (Greene-Vermillion) ili „debrisindeksu” [11]. Za određivanje ovog indeksa koristi se površina šest zuba koji su ujedno reprezentativni uzorak za čitavu denticiju. Merenje je vršeno sondom, i to samo na izniklim zubima. Prosečan indeks je dobijen sabiranjem indeksnih vrednosti za pojedine zube i deljenjem ovog zbira sa brojem posmatranih zuba. Ukoliko je neki zub nedostajao, on se nije mogao zameniti susednim zubom. Grinov indeks tvrdih zubnih naslaga (ITN) ili „kalkulus indeks” određivan je na istim indeksnim zubima kao i debris-indeks. Posle utvrđivanja čvrstih naslaga na reprezentativnim zubima, prosečan indeks je dobijen sabiranjem dobijenih vrednosti i deljenjem sa brojem pregledanih zuba. Oba indeksa zajedno daju indeks oralne higijene (IOH), koji se često koristi u epidemiološkim studijama [11].

Za procenu stanja parodoncijuma korišćen je tzv. indeks $\mathrm{u}$ zajednici i potreba lečenja (engl. community periodontal index of treatment needs - CPITN) [12], koji se u literaturi češće koristi pod skraćenicom CPI. Pri određivanju ovog indeksa korišćena je posebna parodontološka sonda, na čijem se vrhu nalazi kuglica prečnika $0,5 \mathrm{~mm}$, koja olakšava otkrivanje subgingivalnih konkremenata. S obzirom na to da ju je odobrila Svetska zdravstvena organizacija (World Health Organization), često se zove i „WHO sonda”. Izračunavanje ovog indeksa kod dece i omladine uzrasta 7-19 godina je modifikovano shodno preporukama Svetske zdravstvene organizacije. Pregledano je samo šest stalnih zuba: 16, 11, 26, 36, 31 i 46. Kada se procenjuje stanje parodoncijuma dece uzrasta 7-11 godina, ne preporučuje se merenje dubine sulkusa, odnosno džepa. Kod dvanaestogodišnjaka stanje parodoncijuma određivano je na osnovu kliničkog stanja gingive i postojanja čvrstih naslaga, dok je kod petnaestogodišnjaka merena dubina parodontalnog džepa pomoću parodontalne sonde. Upisivana su najteža oštećenja parodoncijuma u odgovarajući sekstant. Kada je to registrovano, dalja merenja bila su nepotrebna. Pojedinačni CPITN osobe predstavljao je najteži nalaz u pregledanim sekstantima, a na osnovu utvrđenog boda procenjivan je rizik za nastanak parodontopatije. Deca kod koje je zabeležena bodovna vrednost 1 smatrala su se osobama kod kojih postoji rizik od razvoja gingivitisa.

\section{REZULTATI}

Dobijeni podaci su pokazali da je prosečna vrednost IMN celokupnog uzorka 0,86. Iako je uočena promena u vrednostima između škola, gde su najveće vrednosti zabeležene kod dece koja su pohađala OŠ „Veselin Masleša” iz Foče, međugrupnom analizom dobijenih podataka nije uočena statistički značajna razlika. Kod dečaka svih škola bez obzira na uzrast ustanovljene su veće prosečne vrednosti IMN u odnosu na devojčice $(1,01$ prema 0,68$)$. Studentovim t-testom dobijena je visoko statistički značajna razlika između polova $(\mathrm{t}=6,333 ; \mathrm{p}<0,01)$. Veće prosečne vrednosti IMN zabeležene su i u grupi petnaestogodišnjaka $(0,92)$ u odnosu na dvanaestogodišnjake $(0,82)$. Poređenjem ovih vrednosti dobijena je statistički značajna razlika između dve grupe učenika $(t=1,967 ; p<0,05)$.
Posmatrajući raspodelu prosečnih vrednosti ITN, uočeno je da su najveće vrednosti bile kod dece koja su pohađala OŠ „Sveti Sava” iz Miljevine, a najniže u OŠ „Ljutica Bogdan” iz Kalinovika. Razlika, međutim, nije bila statistički značajna. Prosečne vrednosti ITN za čitav uzorak ispitanika bila je 0,13 . Kod dečaka su utvrđene nešto veće prosečne vrednost ITN u odnosu na devojčice, ali bez statističke značajnosti. Kod učenika uzrasta od 12 godina takođe su zabeležene veće prosečne vrednost ITN u poređenju sa petnaestogodišnjacima $(0,17$ prema 0,09$)$. Ova razlika bila je visoko statistički značajna, što pokazuju i vrednosti Studentovog t-testa $(t=3,201 ; \mathrm{p}<0,01)$.

Prosečna vrednost IOH za celokupan uzorak ispitanika bila je 0,99 . Prosečna vrednost ovog indeksa kod dečaka $(1,16)$ i petnaestogodišnjaka $(1,11)$ bila je veća nego kod devojčica $(0,78)$ i dvanaestogodišnjaka $(0,91)$. Razlike između posmatranih obeležja ukazale su na visoko statistički značajnu razliku, kako između polova $(\mathrm{t}=5,589 ; \mathrm{p}<0,01)$, tako i između starosnih grupa ispitanika $(\mathrm{t}=2,705 ; \mathrm{p}<0,01)$.

Rasprostranjenost i učestalost oboljenja potpornog aparata zuba procenjivana je primenom CPITN (Tabela 1). Najveće vrednosti zabeležene su u OŠ „Veselin Masleša” u Foči, a najniže u OŠ „Ljutica Bogdan” u Kalinoviku. Jednofaktorskom analizom varijanse dobijena je visoko statistički značajna razlika između učenika koji pohađaju školu „Veselin Masleša” i ostalih škola $(F=3,933 ; p<0,01)$. Poređenjem dobijenih rezultata, između ostalih škola nije uočena statistički značajna razlika. Prosečna vrednost CPITN za čitav uzorak ispitanika bila je 1,29.

Posmatrajući učestalost promena na potpornom aparatu zuba u odnosu na pol i uzrast učenika, uočene su razlike. Kod dečaka je utvrđena veća prosečna vrednost CPITN u odnosu na devojčice $(1,39$ prema 1,17$)$; ova razlika bila je visoko statistički značajna $(t=2,944 ; \mathrm{p}<0,01)$. Statistička značajnost $(\mathrm{t}=2,022$; $\mathrm{p}<0,05$ ) zabeležena je u odnosu na uzrast ispitane dece (dvanaestogodišnjaci - 1,23; petnaestogodišnjaci - 1,38).

Zdrav parodoncijum imalo je 14,6\% ispitanika, dok su kod $8,7 \%$ petnaestogodišnjaka dijagnostikovani parodontalni džepovi. Najčešća vrednost CPITN bila je 1, a zabeležena je kod nešto više od polovine ispitanika (Tabela 2). Među njima je bilo 27,9\% dečaka i 22,9\% devojčica, odnosno 35,4\% dvanaestogodišnjaka i $15,4 \%$ dece uzrasta od 15 godina. Uočena razlika bila je visoko statistički značajna i u pogledu pola $\left(\chi^{2}=15,824\right.$; $\left.\mathrm{p}<0,01\right)$ i u odnosu na uzrast ispitanika $\left(\chi^{2}=19,423 ; p<0,01\right)$. Kod dečaka i dvanaestogodišnjaka zabeležene su veće vrednosti ovog indeksa.

\section{DISKUSIJA}

Epidemiološka istraživanja oboljenja parodoncijuma bave se proučavanjem pojave i rasprostranjenosti oboljenja potpornog aparata zuba. Na osnovu toga mogu se preduzeti odgovarajuće mere prevencije i terapije ovih oboljenja, ali i planirati materijalna sredstva, kadrovi i druge mere za njihovo sprečavanje i suzbijanje. Podaci o rasprostranjenosti gingivitisa i parodontopatija se dosta razlikuju, jer nije primenjena jedinstvena metodologija za njihovo registrovanje. Na osnovu rezultata opsežnih studija može se zaključiti da je učestalost gingivitisa i parodontopatija i dalje visoka, ali da se težina i progresija smanjuju. Zbog neizbežne subjektivnosti pri proceni izraženosti gingivitisa i nemogućnosti objektivnog sagledavanja oštećenja kosti bez radiografskih snimaka, i dobijeni rezultati se veoma razlikuju. 
Nedavno rađena studija na području Bosne i Hercegovine pokazuje da je $43 \%$ dvanaestogodišnjaka imalo zdrava parodontalna tkiva, iako je kod isto toliko ispitanika zabeleženo i krvarenje nakon sondiranja [13]. Učenici koji su bili obuhvaćeni programom prevencije imali su bolju oralnu higijenu $(\mathrm{IOH}=0,95)$ nego deca koja nisu obuhvaćena ovim programom [14]. U istraživanju koje je obavljeno kod dvanaestogodišnjaka u Crnoj Gori prosečna vrednost IMN bila je 1,086. Dečaci iz seoskih delova Crne Gore imali su značajno više mekih naslaga. Prosečna vrednost ITN za iste ispitanike bila je 0,65 . Kada je reč o parodontalnom stanju čitavog uzorka ispitanika, 64\% dvanaestogodišnjaka imalo je zdrava parodontalna tkiva, dok je kod $31,89 \%$ gingiva krvarila tokom sondiranja [15]. Kod dvanaestogodišnjaka i petnaestogodišnjaka koji žive u selima na Kosovu i Metohiji ustanovljene su niže vrednosti indeksa mekih i čvrstih naslaga nego kod njihovih vršnjaka iz grada. Zdrav parodoncijum je utvrđen kod 14,6\% ispitanika, dok su kod najvećeg broja $(40,8 \%)$ dijagnostikovani supragingivalni i subgingivalni konkrementi ili isturene ivice plombi [16]. Ovi rezultati su slični našim kada je zdrav parodoncijum u pitanju. Najnoviji podaci dobijeni istraživanjem iz 2009. godine koje su obavili saradnici Klinike za dečju i preventivnu stomatologiju Stomatološkog fakulteta u Beogradu za potrebe izrade preventivnog programa Republike Srbije pokazali su da je prosečna vrednost gingivalnog indeksa kod dvanaestogodišnjaka 0,5 . Zdrav parodoncijum u najmanje tri sekstanata zabeležen je kod $46 \%$ petnaestogodišnjaka: najbolje stanje bilo je kod dece iz Zaječarskog okruga (96\%) i Severnobanatskog okruga (76\%), a najgore kod ispitanika koji žive u Nišu (16\%) i Zlatiborskom okrugu (16\%) [17]. U studiji zagrebačkih autora krvarenje gingive i zubni konkrementi, kao početni znaci bolesti parodoncijuma, uočeni su kod 82\% najmlađih ispitanika (15-19 godina) [18].

Petersen (Petersen) i Ogava (Ogawa) [8] su razmatrajući moguće načine prevencije parodontopatija upoređivali vrednosti CPITN među različitim starosnim grupama. Kod mladih u Evropi (15-19 godina) zdrav parodoncijum je zabeležen kod oko $20 \%$ ispitanika, dok su kod oko 55\% uočeni kalkulusi i krvarenje nakon sondiranja. Studija rađena u južnoj Italiji pokazala je da je kod većine ispitanika na zubu 11 bilo najmanje konkremenata ili krvarenja pri sondiranju, dok je najugroženiji bio zub 46 [19]. Vrednost od jednog boda CPITN zabeležena je kod 39,7\% pregledanih dvanaestogodišnjaka u Mađarskoj, dok je $28 \%$ učenika imalo zdrav parodoncijum [20]. Krvarenje iz gingive i postojanje konkremenata utvrđeno je kod $90 \%$ dvanaestogodišnjaka iz Portugala, dok je kod 74,5\% zabeležena zadovoljavajuća higijena usta i zuba $(\mathrm{IOH}=0,7-1,8)$ [21]. Vršnjaci iz privatnih škola u Abu Dabiju su u najvećem procentu imali zadovoljavajuću oralnu higijenu (60,33\%), a samo kod 3,30\% ustanovljena je loša higijena usta i zuba [22]. Primenom parodontalnog indeksa potvrđeno je da 57\% dvanaestogodišnjaka iz zapadne Afrike ima gingivitis ili konkremente, a samo $22 \%$ zdrav parodoncijum [23]. Šestogodišnja studija u Hong Kongu tokom koje su posmatrane promene parodontalnog zdravlja dece od detinjstva (12 godina), tokom adolescencije (15 godina), do rane odrasle dobi (18 godina) utvrdila je da se sa starenjem smanjuje procenat dece sa zdravim parodoncijumom, a povećava procenat dece s konkrementima (sa 57,9\% kod dvanaestogodišnjaka na 95,5\% kod osamnaestogodišnjaka) [24]. Krvarenje gingive nakon pranja zuba zabeleženo je kod 15,9\% dvanaestogodišnjaka iz Rio de Žaneira [25].

\section{ZAKLJUČAK}

Zdravlje gingive i parodoncijuma kod dece u Republici Srpskoj nije na zadovoljavajućem nivou. Rezultati istraživanja su pokazali da samo 15\% dece ima zdrav parodoncijum. Posebno zabrinjava podatak da su kod $8 \%$ mladih uočeni teži znaci oboljenja parodoncijuma, odnosno utvrđeni su parodontalni džepovi dubine 4-5 mm. Neophodno je bolje organizovati preventivnu službu i podstaći promociju oralnog zdravlja, te popularisati važnost i značaj dobre higijena usta i zuba. 